There can be no doubt that all that portion of the work which contains translations from the "Monographia" of Fries will be exceedingly valuable to British mycologists, and this extends through the whole of the first volume and 165 pages into the second; the only regret being that the few remaining species, which have not as yet been recorded in these Isles, were not inserted in brackets, or published as an appendix, so that the whole of Fries's excellent work might have been in the hands of every mycologist in this country. Perhaps even now such an appendix might be published, and no doubt it would meet with a hearty welcome.

Despite of such strictures as we have been impelled to make, we venture to hope that the present edition will soon be exhausted, and that its author will be called upon to prepare a new and revised edition, with a key to all the mysteries of the old one.

M. C. C.

\section{THE OCEAN}

Der Ozean. Von Otto Krümmel. (Leipzig und Prag: Freytag-Lempsky, 1886.)

THE great interest which oceanographical studies have aroused within the last few years is shown in a marked manner by the publications destined to popularise the notions acquired respecting this vast and important chapter of physical geography. Not long after the appearance of the "Lehrbuch der Ozeanographie" by Boguslawski, whose untimely death has interrupted the publication of the second volume, we have a new and small manual by Dr. Otto Krümmel, whose name is already known to occanographers.

This little treatise is clearly written, and the most important general notions concerning the physical geography of the sea are well stated, and discussed with ability. 'The author has succeeded in expressing briefly the essential notions about the ocean, which have been recently acquired by the Challenger and other deep-sea expeditions.

The author describes, in the first place, the ocean's surface and its subdivisions ("Die Meeresflächen und ihre Gliederung "); discusses the relation of oceanic and terrestrial areas from the point of view of their respective sizc.; indicates the distribution according to hemispheres; and points out the classification he has adopted into nceins, properly so called, with their general systems of ocean currents, and secondary seas, which are more or iess cut off from the great oceans. The secondary seas are again subdivided into interior, or inter-continental, and border seas, situated on the outer edges of the continents. The volume of oceanic water is then estimated. In the second chapter the interesting questions connected with the deformation of the level and surface of the ocean, owing to the attraction of the continental masses, are examined The depths and contours of the ocean basins are next pointed out, and the work of the Challenger and other deep-sea expeditions, together with the apparatus employed, is described. The observations of the Chatlenger upon the nature and distribution of deep-sea deposits are summarised. The physical and chemical properties of sea-water are set forth in a special chapterthe salinity of the ocean, its distribution and origin; the gas contents; the transparency and colour, are, in turn, treated of. After having made known the principal phenomena regarding the temperature of the ocean and its distribution, Krümmel treats of the glacial phenomena of the Arctic and Antarctic Oeeans, pointing out the limits of the floating ice and icebergs in each region, and the influence of these regions on the questions of general oceanic circulation. The last chapter is reserved for a consideration of the movements of water, such as currents, waves, and tides.

Such is the general order and method of this manual. There is no attempt to give any general notion of the life of the shores, deep sea, and surface of the ocean, or of any of the phenomena due to organisms. The author shows himself to be everywhere au courant with the most recent discoveries in his subject. It would appcar, however, that he has not had an opportunity of consulting the "Narrative of the Cruise of the Challenger," published last ycar, or he would have embraced in his descriptions some additional interesting details and general views. The work is illustrated by many woodcuts and small charts, some of which are instructive, others conveying little information to the reader, but when the low price of the book (one shilling) is remembered it would be unfair to criticise closely these illustrations. Dr. Krimmel has attained the object he had in view-to popularise in a scientific manner our knowledge relative to the plysical geography of the sea, a subject full of interesting questions for all cultured minds.

J. M.

\section{LETTERS TO THE EDITOR}

[The Editor does not hold himself responsible for opinions expressed by his correspondents. Neither can he undertake to return, or to correspond - with the writers of, rejected manuscripts. No notice is taken of anonymous communications.

[The Editor urgently requests correspondents to keep their letters as short as possible. The pressure on his space is so great that it is impossible otherwise to insure the appearance even of communications containing interesting and novel facts.]

\section{On the Connection between Chemical Constitution and Physiological Action}

As regards Dr. Brunton's letter in last week's NATURE (p. 617), I would express myself as more than satisfied with the personal explanation, but Dr. Brunton has not noticed the mo $t$ important point to which I wished to call attention, viz. that whatever may be the value of my experiments, as showing a con nection between physiological action and chemical constitution, the researches of Crum Brown and Fraser have really no bearing on the subject, for the simple reason that they had no knowledge of the chemical constitution of the re-agents they employed. There is an old receipt for cooking a hare which commences "First catch your hare," and in attempting to show the influence of change in chemical constitulion on phy iological action, it is well first to get a constitution. In the last ed tion of Watts's "Organic Chemistry" (1886) it is stated, "All these bases (the alkaloids), like the anines, are derivatives of ammonia, but their molecular structure is for the most part unknown." Even as regards inorganic compounds, our knowledge of their chemical constitution is not the most definite, but I believe that the arrangement of the elements in isomorphous groups expresses most clearly the resemblance in the chemical constitution of their compounds.

After again reading carefully Dr. Brunton's paper, I must confess that I cannot find anything showing the connection between chemical constitution and physiological action, except, perhaps, in the case of the alcohols. Here we have a class of bodies in which the different members of the series have probably the same relation to each other as the elements in the same isomorphous group, and it is an interesting fact that not 